\title{
Legal Respect for Children from Sirri's Marriage in the Perspective of Islamic Marriage Law and Regulations Indonesian Law in the District Labuhanbatu
}

\author{
Khairani Amalia Tambunan ${ }^{1}$, Sriono $^{2}$, Risdalina Siregar ${ }^{3}$ \\ ${ }^{1,2,3}$ Faculty of Law, Labuhanbatu University, Indonesia \\ sriono.mkn@gmail.com
}

\begin{abstract}
Sirri marriage is a marriage that is legal according to the viewpoint of the Islamic religion, while a legal marriage according to the provisions of Articles 1 and 2 of the Marriage Law is that apart from being carried out on the basis of religion it must also be registered. This study aims to determine the legal consequences for children resulting from unregistered marriages based on Islamic law and statutory regulations. This study uses an empirical juridical method, which is conducting field research, in order to support data related to this research by conducting research at the Religious Courts.. The results showed that Labuhanbatu Regency is an area where many people still carry out unregistered marriages or sirri marriages. This can be seen from the data from the Rantauprapat Religious Court from 2018 until now, there have been 53 recorded cases regarding under-handed marriages that have been ordained. So that the legal consequence of the child resulting from a Sirri marriage has the status of an out-of-wedlock child and he cannot accept the rights of the child as a child from a legal marriage based on the marriage law. In the life of the nation and state, all citizens are obliged to obey and be bound by the prevailing laws and regulations in Indonesia.
\end{abstract}

Keywords

legal consequences, children, simi marriage; islamic law

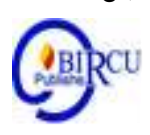

\section{Introduction}

In Indonesia the majority adheres to the Islamic religion, which implements marriage must follow the procedures as stated in the marriage law. However, basically for the community there are still many people whose marital status is not registered as a state, some people carry out religious marriages (nikah sirri), this is has legal consequences on the child's position and the status of the child born and to his wife. If the marriage is not registered under the law, the child only has civil relations with the mother and the mother's family; unless it is scientifically proven (DNA test) which shows that the child born is his / her flesh and blood.

The basic principle in marriage is to legalize the relationship between a man and a woman, which society calls a husband and wife relationship. The existence of this relationship is expected to result in rights and craftsmanship between husband and wife which are justified according to religious demands. From a religious perspective, it is clear that marriage is a sacred contract between a man and a woman. The goal is to form a sakinah, mawadah and spiritual family. The marriage contract is certainly guided by the terms and harmony of the marriage. Marriage is not allowed to contradict the stipulated conditions and harmony.(Supriyadi, 2017). The requirement of a marriage is that a man and a woman are both physically and mentally mature (Maisarah et al., 2019). Often the people of Indonesia, especially Labuhanbatu, ignore the rules stipulated in the Marriage 
Law relating to registered marriages so that sirri marriages occur (Aziz, 2018).

The following kinds of Sirri marriages:

1. Marriage carried out without a marriage guardian.

2. Marriages that are carried out without being registered by PPN officers who are under the authority of the KUA or also called underhand marriages.(Prayitno, 2020)

According to Islamic law nika sirri is valid if (there are guardians, witnesses, consent, qabul and dowries) In article 2 paragraph (2) of the Marriage Law which reads "Every marriage is recorded according to the prevailing laws and regulations" based on Law No. 16 of 2019, on the amendment of Law No.1 of 1974 concerning marriage. This means that sirri marriages are legal only in terms of religion, not by the state, because based on the above law, marriage must be registered according to Law article 2 paragraph (2) of the Marriage Law number 16 of 2019, on the amendment of law No.1 year. 1974 concerning marriage. "Sirri marriages are legal according to Islamic religious law in the implementation of the legal guardian (biological father) or brother of the father, a religious figure who is declared the judge's guardian.(Maloko, 2014)

As stated in the holy book Al-Qur'an surah An-Nisa verse (1):

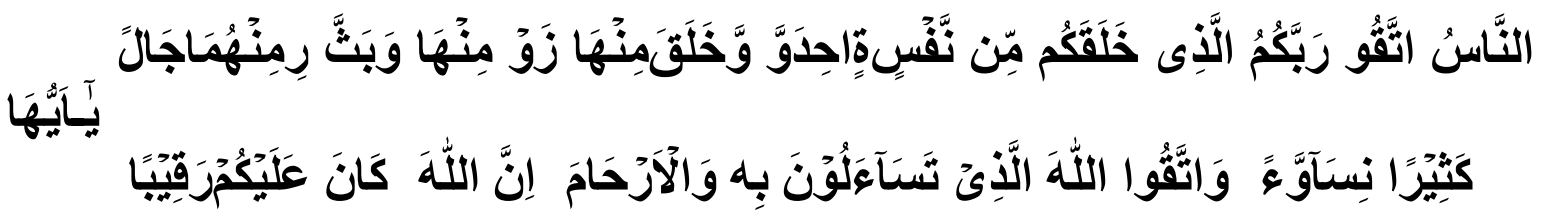

"O people, fear your god who created you from one self (adam), and Allah created his partner (Eve) from him, and from both of them, Allah gave birth to many men and women. Fear Allah, by whose name you ask for each other and maintain kinship. Indeed, Allah is always watching over you." Humans were created in pairs.

Legal marriage according to Islamic law makes the birth of a child as a legal descendant following the lineage or blood of the parent (father). If the marriage does not follow the Islamic religious law, the marital status is not considered valid (zina) and the birth of the child follows the lineage of the mother and the family of the mother and is not entitled to inheritance from the man (father) and the family from the father. It is clear in Islamic law that marriage is carried out legally according to Islamic law and the regulations of the Marriage Law Article 2 paragraph (1), (2) based on Law Number 1 of 1974, on the amendment to Law Number 16 of 2019 which set in the State of Indonesia.

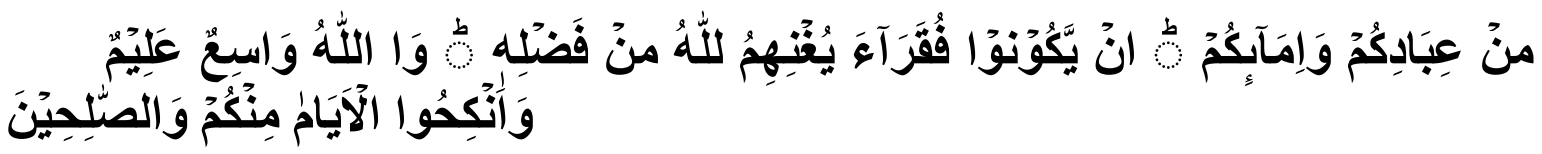

Meaning: "And marry those who are alone among you, and those who are worthy (married) from your female servants. If they are poor, Allah will empower them with His gift. And Allah is vast, His gift, All-knowing". 2 (Surah An-Nuur: 32).

The legal consequence is that children born from sirri marriages are not recognized as heirs of the biological father based on the marriage law. Children born from Sirri marriages are not entitled to demand a living, education fees or inheritance from their father. Children born out of wedlock or as a result of illegitimate husband and wife relationships only have a lineage relationship, the rights and obligations of living as well as rights and inheritance relationships with their mother and mother's family, not with the father/father (ganetic) unless the father still wants to be responsible and continue to base their rights and obligations under Islamic law. Another legal consequence of a Sirri 
marriage to children is that the child cannot obtain a birth certificate with an application for a marriage certificate from his father and mother, but can arrange for a birth certificate in a civil registry office on the basis of KK, KTP and issuance of birth certificates written "marriage has not been registered in the country". This can be seen from the birth certificate application submitted to the civil registry office. However, if the legal status of the father is not known, the child's birth certificate will be recorded as the mother's child.

A marriage has a legal consequence between husband and wife, giving rise to rights and obligations in both religious and state law. Including children born to them have a very important position as successors of their offspring. The existence of blood relations between the offspring of children and their parents results in legal relations in society. Children are reviewed from the origin of legitimate children, outside marriage children (children of sirri marriage and adopted children). Legitimate children are as stipulated in article 22 of Law No.1 of 1974 in conjunction with Law No. 16 of 2019 are children born to their parents who are bound by a legal marriage according to the state. Article 99 of the compilation of Islamic law states that a legitimate child is a child born from a legal marriage and the result of the seed of the husband and wife who gave birth so that the child born is declared legitimate. A mother who gives birth to a child born from an unmarried (illegitimate) parent is considered an illegitimate child or a child outside of marriage. According to Law no. 23 of 2002 concerning child protection states:

Every child in the care of a parent, guardian or other party responsible for the caregiver has the right to receive protection from treatment:

1. Discrimination

2. Exploitation or sexual

3. Neglect

4. Violence and abuse

5. Injustice

6. Mistreatment as regulated in articles 22, 23, 24, 25 of Law No. 23 of 2002 concerning child protection. (Law of the Republic of Indonesia Number 23 of 2002 concerning Child Protection, nd)

\section{Research Methods}

This type of research is juridical empirical is a method of legal research that is carried out regarding the implementation of normative legal provisions by going into the field at any particular legal event that occurs in society. This research refers to data obtained from the field such as sources and respondents who were interviewed in the field, as well as library materials, namely journals, theses and laws related to the title of the researcher.

\section{Results And Discussion}

\subsection{The Status of the Child Born in Sirri Marriage}

Children born from unregistered marriages are considered as illegitimate children (considered illegitimate) by the State so that the legal consequence is that the child only has a civil relationship with the mother and family, while the civil relationship with the father does not exist (articles 42 and 43 of the Marriage Law. and article 100 Compilation of Islamic Law). The sound in Law No. 1 of 1974 regulates the position of out-of-wedlock children in Article 43, namely: 1. Children born outside of marriage only have a civil relationship with their mother and their mother's family. 2. The position of the child 
referred to in paragraph (1) above will further be regulated in a Government Regulation. In fact, children born carry children's rights (rights of the child) which in principle should not be treated differently or discriminated against.

According to Shanty Deliana regarding the right to protection, child protection is an effort to create conditions that protect children from carrying out their obligations. Protection of children must be endeavored in various fields of state and social life. (Syanti, 1998).

Status The child's position is closely related to the marriage of their parents. Based on article 2 paragraph (1) of Law Number: 1 of 1974 concerning Marriage which is carried out in accordance with the procedures and laws of each religion, it is valid. Thus, previous marriages performed by a couple are legal, even though they are only carried out in the manner of a religious marriage. Article 2 paragraph (2) of the Marriage Law confirms that each is registered according to the applicable Prevailing Laws.

According to Article 1 paragraph (1) of Law No. 23 of 2002 concerning Child Protection, a person who is not yet 18 (eighteen) years old, including a child who is still in the womb, is born alive so that the child has the most basic rights and no one takes away the child's rights. In addition, the teachings of the Islamic religion highly uphold children's rights, because children are the future as the Prophet Muhammad said, "Today's youth are the leaders of the future". In general, according to experts, it is said that children are a gift from an almighty God who must be guarded, educated, as a provision of resources, children are priceless wealth. A child is present as a mandate from God to be cared for,(Law of the Republic of Indonesia Number 23 of 2002 concerning Child Protection, nd).

Literally a child is someone who is a forerunner who will continue the generation of his family, nation and state. Children are also an asset of human resources that can help build the nation and the State. Understanding children from the religious aspect In the viewpoint built by religion, especially in this case is the religion of Islam, children are weak but noble creatures, whose existence is the authority of the will of Allah SWT as their creator.

Because children have a noble life in the view of Islam, they must be treated humanely as if they are given a living both physically and mentally, so that one day the child grows up to be a child with noble character, such as being responsible for socializing himself to achieve his life's needs in the future. Based on the legal aspect and statutory regulation, there is pluralism regarding the definition of a child, this is as a result of each statutory regulation that regulates separately the child's own regulations. The definition of a child in legal standing includes the meaning of a child from the viewpoint of the legal system or called kedududkan in a special sense as a legal subject.

According to civil law, the definition of a child according to civil law is built from several aspects of civilization that exist in children as a legal subject who is unable.

a. Immature status (age limit) as legal subjects.

b. Children's rights in civil law. Article 330 Kuhperdata provides that a child is a person who is not yet mature and someone who has not reached the legal legitimacy age limit as a legal subject or as a national legal subject determined by civil legislation. In the provisions of civil law, children have a very broad position and have a very large role. It is important, especially in terms of providing protection for the civil rights of children, for example in the issue of distribution of inheritance, so that a child who is in someone's womb is deemed to have been born if the interests of the child want it as referred to in article 2 of the Civil Code.(Civil Code, nd) 
The definition of a siri marriage according to Imam abu hanifah, what is meant by a siri marriage is a marriage that cannot present a guardian and does not register the marriage at the KUA (Office of Religious Affairs). She stipulates that women who are mature and sensible (under normal conditions) are allowed to choose their own future husbands. Sirri marriage is a marriage that is carried out in secret. Etymologically the word "sirri" comes from Arabic, namely "sirrun" which means secret, silent, silent, hidden as opposed to the word alaniyyah, which is open. The word sirri is then combined with the word nikah so that it becomes nikah sirri to say that marriage is done secretly or in secret. So this secretly and secretly brings up two understandings, that is, a marriage that was secretly not announced to the halayak or a marriage which was not known or registered in the State institution. In the terminology of maliki fiqh, a sirri marriage is a marriage which, according to the husband's message, the witnesses keep it secret for his wife or congregation, even if it is a local family. According to the hanafi school, maliki and syafii sirri marriages are not allowed in Islam. Marriage can be canceled and the two perpetrators can be subject to punishment had (whipping or stoning) if there has been sexual relations between the two and confessed or with the testimony of 4 witnesses. Abdul gani explained that sirri marriage is actually not in accordance with "magashid sharia", because there are several purposes of sharia that are omitted, namely:

a. The marriage must be announced (known to the public).

b. The protection of the rights of women in marriage under the hands of women has a lot of rights disadvantaged, because in the event of a divorce the woman does not get anything from her ex-husband.

c. For the benefit of mankind, marriage under the hands of it does more harm than good.

d. There are conditions in a polygamous marriage that requires permission from the first wife. Second, third and so on marriages that do not get permission from the first wife are usually carried out under the hands, so that the first wife does not know that her husband has remarried another woman.(Atun, nd)

There are so many people who encourage the Indonesian people to carry out a sirri marriage or marriage under the hands, either with fellow Indonesians or with foreigners. Most people believe that a sirri marriage is considered legal according to Islamic law if it fulfills the harmonious conditions and conditions of marriage, even though the marriage is not recorded. Formally. Likewise, on the contrary, a divorce is considered valid if it has fulfilled the terms and conditions, even though the divorce is carried out outside the court. As a result of this fact, a kind of legal dualism prevails in the State of Indonesia, namely legal marriage according to Islamic religious law but does not have the power. Official law of the State or not recognized by the State. Until now there is no accurate data that shows the size of the number of perpetrators of sirri marriages in Indonesia. Especially in the Rantauprapat area, Labuhanbatu. This is because the perpetrators of sirri marriages are not known to many people. Marriages that are carried out in secret or covered up are very prone to the emergence of many problems in domestic and social life, even though the results of harm are far more visible than benefit.

\subsection{The Legal Consequences of Sirri Marriage from the Perspective of Islamic Law}

Sirri marriage has a positive impact on a wife and children.

a. can cover individual rights. By doing a sirri marriage it can cover the interests of the parties behind the occurrence of the marriage. And sirri marriages are usually carried out as an effort to cover up disgrace in the family so that people do not know what is the background of the marriage. Like the thing is pregnant out of wedlock. 
b. no worries about committing adultery. One of the reasons for the sirri marriage is so that there is no concern about committing adultery, whether it happens among teenagers who are still in school or among adults (men who already have wives). Sirri marriage is often considered the best solution than falling into a grave sin or adultery.(Asripa, Yulistian Hartini, Ike Septiyanti, Nurul Widiya Agustin, Nikmatul Musayadah, 2020)

Regarding the Sirri marriage, it is still a long debate. According to Article 4 of the Compilation of Islamic Law ("KHI"), marriage is legal, if it is carried out according to Islamic law in accordance with Article 2 paragraph (1) of Law no. 1 of 1974 concerning Marriage ("UUP") which states "Marriage is legal if it is carried out according to the law of each religion and belief." However, such marriages must be reported and recorded at the Office of Religious Affairs or in the Civil Registry for non-Muslims. This is in accordance with the provisions of Article 2 paragraph (2) of the Marriage Law which states "Every marriage is recorded according to the prevailing laws and regulations".(Armansyah Armansyah, 2017)

As a result of the law on the wife, the wife is not a legal wife and therefore has no right to support and inheritance from the husband and is not entitled to this property in case of separation. For a child, his status is an out of wedlock and therefore he only has a civil relationship with his mother and his mother's family and at any time his father can deny the existence of the child, besides that he is not entitled to a living, education costs, and inheritance from his father. If it is returned to the Islamic marriage law, while the marriage has fulfilled the terms and conditions, the marriage is valid and entitled to the provisions outlined in the Islamic marriage law, such as the legal relationship between a wife and husband, child and both parents inheritance and settlement in the event of a divorce or when one of the husband or wife dies. There are many incidents that cause a person not to register his marriage at the registration institution. There are those who are due to cost factors, or are unable to pay for the administration of registration so that they are not registered but are not kept secret, are not yet old enough to carry out a state marriage, some are because they are afraid of being caught violating the rules that prohibit civil servants from marrying more than one or what is referred to as ( Polygamy), and so on. There are also marriages that are kept secret because of certain considerations, for example because they are afraid of getting a negative stigma from people who already consider the taboo (greed) of unregistered marriage, or because of complex considerations that force a person to keep his marriage a secret. For those who are afraid of being discovered by the public, their marriage is not registered and kept secret.(Wasian, 2010).

The legal consequence of a child in a sirri marriage according to state law is that a child born from a siri marriage where the unregistered marriage is considered non-existent by the state because it is not registered. Thus, a child born from a unmarried marriage is considered an out-of-wedlock even though the child is born from a marriage that is legal under Islamic law. The consequence is that children born from unregistered marriages only have a civil relationship with the mother and the mother's family.(Rusydi, 2019)

Another legal consequence of sirri marriage to children is that the child cannot obtain a birth certificate. this can be seen from the birth certificate application submitted to the civil registry office. If the child is unable to show the marriage certificate of the child's parents, then the child's birth certificate is considered an illegitimate child, the name of the biological father is not written and only the biological mother is written. Information in the form of status as an out-of-wedlock child and not recording the name of the father will have a profound social and psychological impact on the child and the mother. (Olivia, 2014) 
However, unregistered marriages are seen as not complying with statutory provisions and often have a negative impact on the wife and children born to them in relation to their rights such as income or inheritance rights. Demands for the fulfillment of these rights often lead to disputes. Because the demands will be difficult to fulfill because there is no evidence of a valid legal marriage record. However, to avoid harm, the participants of ijtima 'ulama agreed that marriage must be officially registered with the competent authority. Apart from that, the registration of marriage is to regulate marriages that exist in the community as well as to determine legal certainty for the community itself, the consequences of which are related to the status of the child born in the future.

Legal measures against the protection of children born from unregistered marriages for Muslims are by submitting a request for the determination of the Itsbat Nikah. Marriage registration is a complement to the State Administration as regulated in the Decree of the Minister of Religion of the Republic of Indonesia Number: 154 of 1991 concerning INPRES Number: 1 of 1991 dated 10 June 1991 concerning the Compilation of Islamic Law.(Risdalina Siregar, 2018)

The definition of legitimate child, Referring to your question, it is assumed that the subject/person in the question is Muslim. In article 99 of the presidential instruction number 1 of 1991 concerning the dissemination of the compilation of Islamic law ("KHI") it is stated that, Legitimate children are:

a. children born from legal marriages;

b. the result of the husband and wife's actions outside the womb and being born by the wife.

Referring to Article 1 of Law No.1 of 1974 concerning Marriage ("Marriage Law"), marriage is a physical and spiritual bond between a man and a woman as husband and wife with the aim of forming a happy and eternal family (household) based on divinity. the one and only.

Based on the author's interview with Bpk Sabri Iham SH.MH, the Junior clerk of the Rantauprapat Religious Court, stated that if a marriage in the Islamic religion has never been registered, the marriage can be treated as marriage through the Rantauprapat Religious Court (PA). Meanwhile, the status of the kawinn sirri after it is determined by the Religious Court and after that the marriage can be carried out through the Office of Religious Affairs or KUA.

then the marriage will be legal in the eyes of both the state and the law.

The evidence that must be prepared to prove that the child is the fruit of the man / father in the Religious Court is:

a. confession from man or father

b. there are technological tools that might be able to provide the truth about the matter in question

c. witness witness who can trust the truth.

There are 244 cases of sirrih marriage that have been treated at the Rantauprapat Religious Court from January 2020 to January 2021.

The cases of the claimant for the rights of children to boys who were in the Rantauprapat Religious Court amounted to NIL (none).

The pillars of marriage in Islam include a groom, bride, guardian, two male witness parents, a dowry, and consent and Kabul. But such marriages can become haram if they cause harm or negative impact. The fatwa is the result of the second decision of the Ijtima Ulama throughout Indonesia, at the Gontor Modern Islamic Boarding School, Ponorogo, East Java in 2006. Nikah Sirrih is deemed not to comply with statutory provisions. It also 
often has a negative impact on the wife and children born to them, related to their rights such as maintenance or inheritance rights.

Demands for the fulfillment of these rights also often lead to disputes. Because the demands for a suit were fulfilled because there was no evidence of a valid legal marriage record. However, to avoid harm. Ulama agreed that marriages must be officially recorded at the competent authority. So, MUI appealed to the public to marry legally in accordance with the provisions of statutory regulations. Although sirri marriages are religiously legal, they have no legal force. In the absence of legal force, both the wife and children have the potential to suffer losses due to the marriage. MUI is of the view that the purpose of marriage is very noble and noble to uplift human dignity.

Marriage is not just to fulfill basic human desires or just to fulfill sexual needs. Marriage is a sacred institution that must be guarded and maintained. (Marriage) cannot be denigrated and used as a mere trading commodity. If this happens, then it is the same as degrading human values.

As a result of the law on sirri marriages in Islam, marriages that are not recorded are basically valid according to religious norms because they have fulfilled the pillars of marriage, which should have legal protection as regulated in the compilation of Islamic law. However, these marriages are faced with national legal norms which require that every marriage must be registered in order to obtain legal protection on the basis of evidence of a marriage that is valid according to law. The conflict of norms is actually not on whether or not a marriage has been carried out according to religion, but on the perception of the obligation to record the purpose of which is for legal order.

On the one hand, marriage registration is needed in the plurality of marriage laws, on the other hand, marriage registration provides other evidence besides the marriage certificate so that it is rigid. Legal protection for children resulting from Sirri marriages has been regulated in Indonesian law in two aspects, namely: first, aspects of daily life as a child resulting from marriage, have been regulated in the compilation of Islamic law and fikih munakahat. If the marriage is based on obedience to Allah, then they will follow this rule. Second, from the juridical aspect related to legal relations, it has been regulated through the Constitutional Court (Constitutional Court) decision that a child outside of marriage has a civil law relationship with his biological father, so that he has inheritance rights.

Based on the description above, the government will find it difficult to provide protection for children born from unregistered marriages, in order to obtain a birth certificate which is the child's right after birth. Therefore, it becomes difficult to protect children whose marriages are not recorded if people do not think about the implications of their actions for themselves and their children later. Even though the State has done everything, the regulations made by the state are just regulations People's awareness is needed in order to implement these regulations in order to create a good life for both the child and their parents.

As for the author's interview to the Office of Religious Affairs (KUA), with Mr. Muhammad Sabri, SAg. Declare that marriage must be registered and in a sirri marriage it is not registered in the state but is legal according to religion. Sirri marriages cause a lot of mudhorat, both in the status of children in obtaining inheritance and children's rights over the father and mother. In sirri marriages there are many conflicts in the distribution of inheritance. The distribution of inheritance to sirri children can be done in Islam by way of faroid on the grounds that it can be accepted by other families. 


\section{Conclusion}

Sirri marriages are seen as not complying with statutory provisions and often have a negative impact on the wife and children born to them in relation to their rights such as income or inheritance rights. Demands for the fulfillment of these rights often lead to disputes. Because the demands will be difficult to fulfill because there is no evidence of a valid legal marriage record. However, to avoid harm, the participants of ijtima 'ulama agreed that marriage must be officially registered with the competent authority. Apart from that, the registration of marriage is to regulate marriages that exist in the community as well as to determine legal certainty for the community itself, the consequences of which are related to the status of the child born in the future.

For religious people who are obedient to religion and obey the laws and regulations of marriage, it is better not to marry sirri even though it is legal in the Islamic way because of the very effect it has on women and children who can be left alone so that it is misery for women and children who was born. In my response, I also hope that parents and women who want to get married will refuse if the man proposes a sirri marriage so that the status of wife and child can be legally declared both religiously and in the state.

\section{References}

Armansyah Armansyah. (2017). Perkawinan Sirri Dalam Perspektif Hukum Islam Dan Undang-Undang Nomor 1 Tahun 1974 Tentang Perkawinan. SANGAJI: Jurnal Pemikiran Syariah Dan Hukum, 1(2), 1-16.

Asripa, Yulistian Hartini, Ike Septiyanti, Nurul Widiya Agustin, Nikmatul Musayadah, A. K. (2020). Nikah sirri dalam perspektif islam. Jurnal Imtiyaz, 4(1), 42-61. https://doi.org/10.46773/imtiyaz.v4i1.64

Atun, S. (n.d.). Perlindungan Hukum Terhadap Anak Yang Lahir Di Luar Perkawinan Untuk Mendapatkan Akte Kelahiran Dan Nafkah Dari Ayah Biologisnya.

Aziz, N. (2018). the Great Phenomenon of Online Sirri Marriage for Male and Female. Budapest International Research and Critics Institute (BIRCI-Journal): Humanities and Social Sciences, 1(3), 445-450. https://doi.org/10.33258/birci.v1i3.70

Kitab Undang-Undang Hukum Perdata. (n.d.).

Maisarah, Afrizal, Zulfahmi, Mauliza, F., \& Murni, F. (2019). Minimum Marriage Age: Study of Fiqh of Four Madhabs. Britain International of Humanities and Social Sciences (BIoHS) Journal, 1(2), 149-158. https://doi.org/10.33258/biohs.v1i2.46

Maloko, M. T. (2014). Nikah Sirri Perspektif Hukum Islam. Jurnal Sipakalebbi, 1(3), 120. https://doi.org/10.24252/jsipakallebbi.v1i3.275

Olivia, F. (2014). Akibat Hukum Terhadap Anak Hasil Perkawinan Sirri Pasca Putusan Mahkamah Konstitusi. Lex Jurnalica, 11(2), 1-13.

Prayitno, D. (2020). Tinjauan Yuridis Kedudukan Anak Perkawinan Sirri Dengan Wali Muhakkam Pada Putusan Nomor 130/PDT.P/2019/PA.BBS. Universitas Pancasakti Tegal.

Risdalina Siregar. (2018). Pembagian Harta Warisan Berdasarkan Surat Hibah Wasiat Yang Dititipkan Kepada Notaris Untuk Anak Dilahirkan Dari Perkawinan Orang Tua Yang Tidak Dicatatkan. Jurnal Ilmiah Advokasi, 6(2), 73-92. https://doi.org/10.36987/jiad.v6i2.251

Rusydi, I. (2019). Tinjauan Yuridis Terhadap Hak Waris Anak Hasil Perkawinan Siri. Jurnal Ilmiah Galuh Justisi, 7(1), 1-10. https://doi.org/10.25157/jigj.v7i1.2145 
Supriyadi. (2017). Perkawinan Sirri Dalam Perspektif Hukum Di Indonesia. Jurnal Pemikiran Hukum Dan Hukum Islam, 8(Juni), 1-17.

Undang-Undang Republik Indonesia Nomor 23 Tahun 2002 Tentang Perlindungan Anak. (n.d.).

Wasian, A. (2010). Akibat Hukum Perkawinan Sirri (Tidak Dicatatkan) Terhadap Kedudukan Istri, Anak, Dan Harta Kekayaannya Tinjauan Hukum Islam Dan Undang-Undang Perkawinan. Tesis, Universitas Diponegoro Semarang. 